\title{
Studi Deskriptif Tingkat Toleransi Beragama dan Kematangan Beragama di Kota Tangerang
}

\author{
Adiyo Roebianto, Wenny Hikmah, Iga Nadilah Putri \\ Fakultas Psikologi, Universitas Mercu Buana, Jakarta \\ Corresponding E-mail: adiyo.roebianto@mercubuana.ac.id
}

\begin{abstract}
Tangerang is a city whose people consist of various ethnicities or religions, such as Muslims, Christians, Catholics, and Buddhists. Even in Tangerang, there are quite a lot of temples / temples. In the last 20 years, the people of Tangerang City have never faced horizontal conflicts between religious believers. But interestingly, based on the results of the Setara Institute study in 2018, Tangerang as a city has a tolerance index of 4.58 from a range of scores of 1-7. This figure puts Tangerang in the 61 st position of the 94 cities surveyed. These results can be said to be low. Of course, this is somewhat different from the phenomenon which recorded the absence of horizontal conflicts in Tangerang City. The purpose of this research is to see a picture of religious maturity and religious tolerance in the people of Tangerang city. This study used a quantitative approach, target participants in this study were $150(n=$ 150) participants. The research instrument was a questionnaire containing statements / items related to religious tolerance. Data was collected by means of online administration because this study was conducted during the Covid-19 pandemic. The results of the mean difference test show that there is no significant difference, both in terms of religious tolerance and religious maturity based on the demographic group of age, gender, and education. But in terms of histogram distribution, it shows the outlier score on the variable of religious maturity. Therefore, in general, demographic factors do not affect the variation of religious tolerance and religious maturity. However, the religious maturity score of the people of Tangerang City is relatively low.
\end{abstract}

Keywords: Religious maturity, Religious tolerance, Descriptive Quantitative, Tangerang

\begin{abstract}
Abstrak
Tangerang merupakan salah satu kota yang masyarakatnya terdiri dari berbagai macam etnis atau agama, seperti Muslim, Kristen, Katolik dan Budha. Bahkan di Tangerang, memiliki cukup banyak wihara/kelenteng. Dalam kurun waktu 20 tahun ke belakang, masyarakat Kota Tangerang tidak pernah menghadapi konflik horizontal antar pemeluk agama. Namun menariknya, berdasarkan hasil studi Setara Institute pada tahun 2018, Tangerang sebagai kota yang memiliki indeks toleransi sebesar 4.58 dari rentangan skor 1-7. Angka tersebut menempatkan Tangerang di posisi 61 dari 94 kota yang disurvei. Hasil tersebut dapat dikatakan rendah. Tentu hal ini agak berbeda dengan fenomena yang mencatatkan tidak adanya konflik horizontal di Kota Tangerang. Tujuan penelitian ini adalah untuk melihat gambaran kematangan agama dan toleransi dan beragama di masyarakat Kota Tangerang. Studi ini menggunakan pendekatan kuantitatif, target partisipan dalam penelitian ini sebesar $150(n=150)$ partisipan. Instrument penelitian berupa kuesioner yang berisi pernyataan/item terkait dengan toleransi beragama. Pengumpulan data dilakukan dengan cara online administration disebabkan studi ini dilakukan dalam masa pandemic Covid-19. Hasil uji beda mean menunjukkan bahwa tidak terdapat perbedaan yang signifikan, baik dalam hal toleransi beragama maupun kematangan beragama berdasarkan kelompok demografi usia, jenis kelamin dan pendidikan. Tetapi secara distribusi histogram, menunjukkan adanya skor outlier pada variable kematangan beragama. Oleh karenanya, secara umum factor demografi tidak memengaruhi bervariasinya toleransi beragama dan kematangan beragama. Tetapi skor kematangan beragama masyarakat Kota Tangerang, relatif agak rendah.
\end{abstract}

Kata Kunci: Kematangan beragama, Toleransi beragama, Tangerang, Kuantitatif Deskriptif 


\section{Pendahuluan}

Indonesia dikenal dengan berbagai keberagamannya, dimulai dari ras, agama, budaya, bahkan bahasa. Secara spesifik, agama merupakan hal yang bersifat pribadi, namun menjadi topik yang selalu dibicarakan terutama dari segi penganut agama itu sendiri. Salah satu isu yang cukup kental terkait dengan agama di Indonesia adalah toleransi beragama (Mangunwijaya, 1986).

Di Indonesia, praktik intoleransi beragama pernah terjadi di beberapa daerah. Misalnya konflik antara umat Muslim dengan umat Nasrani pada tahun 2015 di Tolikara, Papua (Umar, 2015). Peristiwa ini terjadi ketika umat Muslim sedang melaksanakan ibadah shalat Idul Fitri, kemudian diserang oleh sekelompok umat Nasrani. Sekelompok umat Nasrani beranggapan bahwa umat Islam dilarang shalat di lapangan sekitar, dikarenakan pada saat yang bersamaan sedang diadakan kebaktian rohani yang jaraknya sekitar 200meter dari lokasi shalat Idul Fitri.

Contoh lainnya misalnya konflik agama yang terjadi di Poso pada tahun 1996. Berbagai sumber informasi menyebutkan penyebab konflik berbeda - beda. Alganih (2016) mengatakan penyebab utama konflik Poso adalah kondisi social-ekonomi, Cinu (2017) mengatakan penyebab konflik Poso adalah adanya ledakan dan tembakan ke arah desa yang mayoritas muslim. Sedangkan menurut Alganih (2016) konflik Poso memiliki penyebab yaitu karena konflik atau pertikaian antar pemuda dari lintas agama, sehingga hal ini mengakibatkan ke konflik lainnya, termasuk politik, ekonomi dan bahkan agama. Konflik ini bahkan hingga menimbulkan korban jiwa yang banyak. Hingga akhirnya kasus ini berakhir ketika mantan Wakil Presiden Indonesia, Jusuf Kalla berperan sebagai mediator atas ummat Islam dan Kristen.

Pada tahun 2018, Setara Institute merilis hasil studi tentang Indeks Kota Toleran (IKT) di Indonesia. Salah satu kota yang dapat dikatakan memiliki tingkat toleransi relative rendah adalah Tangerang (4,58 dari 7), dengan ranking 61 dari 94 kota di Indonesia. Tetapi menariknya adalah berdasarkan telusuran penulis, sejauh ini tidak ada konlik fisik antar umat beragama yang terjadi di Kota Tangerang setidaknya dalam waktu 10 tahun kebelakang.

Berdasarkan data tahun 2018 dari Badan Pusat Statistik (BPS) Kota Tangerang jumlah total penduduk kota Tangerang sebesar 2.185.304 jiwa. Sedangkan berdasarkan data dari BPS Kota Tangerang tahun 2010, sekitar 88,25\% penduduk kota Tangerang adalah muslim, 5,29\% adalah penganut agama Kristen, 2,27\% adalah penganut agama Katolik, 0,14\% adalah penganut agama Hindhu, 3,69\% adalah penganut agama Budha dan sisanya 0,36\% adalah penganut agama Konghucu. Hal ini menggambarkan bahwa Kota Tangerang juga memiliki entitas keberagaman agama yang bervariasi. Selain itu, etnis Tionghoa di Kota Tangerang juga dapat dikatakan cukup banyak. Setidaknya hal ini terbukti dengan adanya 35 wihara/kelenteng yang terdapat di Kota Tangerang (data BPS Kota Tangerang tahun 2014). Data - data tersebut menjadikan Kota Tangerang sebagai kota yang multi etnis dan agama.

Meskipun Kota Tangerang dikatakan sebagai kota yang multi etnis, tetapi menariknya berdasarkan studi Setara Institute sebagaimana diatas, bahwa penduduk Kota Tangerang memiliki Indeks Toleransi yang relative kecil. Padahal, penduduk Kota Tangerang hidup dengan keragaman agama dan suku, bahkan tercatat tidak pernah ada konflik horizontal yang disebabkan oleh SARA, khususnya agama. Hal ini menarik untuk diteliti lebih lanjut, bagaimana tingkat toleransi beragama penduduk kota Tangerang. Studi ini akan focus untuk mendeskripsikan toleransi beragama penduduk Kota Tangerang yang ditinjau secara kajian psikologi dengan pendekatan kuantitatif.

Berangkat dari latar belakang masalah di atas, maka rumusan masalah dalam penelitian ini yaitu bagaimana gambaran toleransi dan kematangan beragama di Kota Tangerang berdasarkan pendekatan kuantitatif deskriptif? Selain itu juga ingin melihat perbedaan toleransi dan kematangan beragama pada jenis kelamin, usia, dan pendididikan.

Toleransi berasal dari kata toleran, yang berarti bersifat atau bersikap menenggang (menghargai) terhadap pendirian/pendapat yang berbeda atau bertentangan dengan pendirian sendiri (Kamus Besar 
Bahasa Indonesia, 2020). Sedangkan dalam Bahasa arab, toleransi diterjemahkan sebagai kata tasamuh yang artinya saling mengizinkan dan saling memudahkan (Gunawan, 2002).

Pada konteks toleransi beragama, Basyir (dalam Gunawan, 2002) mendefinisikannya sebagai sikap menghormati penganut agama lain dan berbuat baik serta adil kepada penganut agama lain tersebut. Sedangkan menurut Nasution (dalam Gunawan, 2002) toleransi beragama tercermin melalui lima hal yaitu melihat kebenaran yang ada pada agama lain; memperkecil perbedaan antar agama; menonjolkan persamaan yang ada antar agama; membina rasa persaudaraan atas Ketuhanan; dan terakhir menjauhi praktik saling menyerang antar agama. Maka itu, menurut penulis, jika dikaitkan dengan toleransi beragama dapat diartikan sebagai sikap menghargai perbedaan antar pemeluk agama. Bahkan sikap toleransi beragama tidak hanya sebatas pada antar pemeluk agama yang sama, tetapi juga antar pemeluk agama yang berbeda.

Selain itu untuk dapat bertoleransi beragama dibutuhkan kematangan dalam beragama. Kematangan beragama adalah konsep yang diperkenalkan oleh Allport (1950). Teori Allport (1950) menyebutkan enam komponen yang mendefinisikan kematangan dalam beragama: (a) kekuatan motivasi dan komitmen agama (yaitu, agama sebagai motif utama yang dinamis mengarahkan kehidupan seseorang), (b) diferensiasi dan kompleksitas pemikiran sehubungan dengan isu agamaeksistensial, (c) komprehansif (memberikan makna bagi kehidupan dan mempromosikan toleransi sudut pandang alternatif), (d) kualitas heuristik (kerendahan hati dan

kesiapan untuk meragukan), (e) mengarahkan dan memiliki konsekuensi moral), dan (f) sifat yang tidak terpisahkan. Allport juga berteori bahwa individu pada umumnya mengambil salah satu dari dua pendekatan umum terhadap agama: (a) agama yang matang, di mana agama sebagai tujuan itu sendiri, dan (b) agama yang belum matang, di mana agama digunakan untuk tujuan lain, diluar agama. Kristensen, Pedersen, \& Williams (2001) memperjelas konsep kematangan beragama dengan menjelaskan bahwa individu yang matang beragama adalah konsistensi atau integrasi antara komponen kognitif dan afektif dari sikap seseorang tentang keyakinan dan praktik keagamaan serta niat pribadi dan perilaku religius yang sebenarnya. Artinya, seseorang tidak hanya berpikir tentang agamanya, tetapi juga merasa kuat, dan bertindak sesuai dengan itu.

Penelitian oleh Golebiowska (1999) di masyarakat Amerika Serikat menunjukkan adanya perbedaan jender pada sikap toleransi politik. Secara umum perempuan dan laki-laki tidak berbeda dalam sikap mereka di sebagian besar wilayah, namun perbedaan gender yang persisten telah diidentifikasi di beberapa domain masalah, termasuk dukungan untuk kebebasan sipil dari kelompok politik out-group.Perempuan digambarkan lebih enggan daripada laki-laki untuk mengizinkan kelompok yang tidak populer untuk menggunakan hak konstitusional mereka; wanita juga tampaknya berbeda dari pria dalam memilih intoleransi target. Di antara orang-orang muda, telah ditemukan gadis-gadis lebih toleran daripada anak laki-laki (Fritzsche, 2006). Studi di Indonesia dengan metode kualitatif menunjukkan ada perbedaan toleransi antara siswa perempuan dan laki-laki di Indonesia (Juwita, Salim, \& Winarno, 2018) Temuan tersebut menunjukkan masih adanya gap toleransi antara siswa perempuan dan laki-laki tingkah laku. Laki-laki cenderung lebih cuek dan perempuan lebih sensitif terhadap perbedaan lingkungan disekitarnya. Namun demikian, laki-laki memiliki kecenderungan lebih diskriminatif dalam memperlakukan perbedaan sedangkan perempuan sedikit lebih toleran. Dua penelitian tersebut belum menunjukkan secara pasti apakah ada perbedaan toleransi antara laki-laki dan perempuan, sehingga diperlukan studi lebih lanjut

Selain itu beberapa penelitian telah dilakukan untuk melihat hubungan antara pendidikan dan toleransi (Weldon, 2006). Studi terpisah telah menunjukkan bahwa hubungan ini tidak hanya karena pemahaman yang lebih baik tentang tuntutan lingkungan sosial untuk bertoleransi di antara mereka yang lebih berpendidikan tinggi (Wagner dan Zick, 1995). Apakah hal sama akan berlaku juga bagi masyarakat Tangerang? 


\section{Partisipan}

Populasi dalam penelitian ini adalah warga Kota Tangerang. Berdasarkan data BPS Kota Tangerang tahun 2018, jumlah total penduduk Kota Tangerang sekitar 2.185.000. Namun yang menjadi kriteria sampel dalam penelitian ini adalah mereka yang minimal berusia 18 tahun hingga maksium 60 tahun. Menurut asumsi penulis, rentangan usia tersebut sudah memahami isi daripada pertanyaan/pernyataan yang ada pada kuesioner penelitian. Oleh karena itu, teknik pengambilan sampel berupa non-probability sampling, dengan menggunakan kriteria secara detail yaitu 1) Berdomisili di Tangerang; 2) Berusia 18 - 60 tahun.

Partisipan dalam penelitian ini yaitu sejumlah 150 orang yang semuanya berdomisili di kota Tangerang. Jumlah partisipan ini memang terbatas dikarenakan pengumpulan data yang dilakukan dalam kondisi pandemic Covid-19, sehingga membatasi ruang gerak tim penulis dalam pengumpulan data. Oleh karena itu, prosedur pengumpulan data akan dilakukan dengan menggunakan kuesioner yang disebarkan secara daring (online). Meskipun terkesan mudah, tetapi pada kenyataannya mengumpulkan data secara daring membutuhkan waktu yang cukup lama untuk mencapai angka 150. Dengan demikian, meskipun mungkin terbatas, tetapi penulis berasumsi bahwa 150 partisipan cukup untuk gambaran deskriptif toleransi beragama masyarakat Kota Tangerang. Subjek memiliki latar belakang pendidikan yang beraneka ragam. Gambaran lebih jelas mengenai subjek penelitian dapat dilihat di Tabel 5.

\section{Instrumen Penelitian}

Variabel dalam penelitian ini yaitu toleransi beragama. Secara konseptual toleransi beragama diartikan sebagai sikap saling menghargai dan menghormati terhadap pemeluk agama. Sedangkan secara operasional, toleransi beragama adalah skor yang diperoleh dari pengukuran sikap menghargai dan menghormati terhadap pemeluk agama. Variabel kematangan beragama terdiri dari tiga aspek yaitu, well-differentiated and self-critical (berpengetahuan luas dan bisa mengkritik diri); motivational force (menjadikan agama sebagai kekuatan motivasi); moral consistency (moralitas yang konsisten); komprehensif; integral; dan heuristik. Menurut Allport (1954) aspek-aspek toleransi terdiri dari dua aspek, yakni pertama ethnic attitude tolerance. Dalam bertoleransi masyarakat cenderung melihat latar belakang suku sebagai suatu hal yang penting. Latar belakang inilah yang mendasari mereka untuk bertoleransi atau tidak. Kedua, nonethnic attitude tolerance. Toleransi terjadi karena suatu masyarakat memberikan standar, aturan, atau kode etik tertentu yang mengatur toleransi. Mereka menjadi toleran karena berusaha conform dengan peraturan yang ada. Selain itu, toleransi bentuk ini terjadi karena seseorang mengembangkan suatu bentuk positif organisasi kepribadiannya. Orang-orang ini memiliki penghargaan positif terhadap orang lain, siapapun ia, mereka mempunyai pandangan terhadap dunia yang positif. Skala yang digunakan yaitu berupa skala Likert, dengan empat kategori respon jawaban sangat tidak setuju, tidak setuju, setuju dan sangat setuju

Table 1. Blue-Print Skala Toleransi Beragama

\begin{tabular}{cccc}
\hline VARIABEL & ASPEK & NOMOR ITEM & JUMLAH \\
\hline & Ethnic Attitude & $1,2,3,4,5^{*}, 6^{*}, 7^{*}, 8^{*}, 9^{*}, 10^{*}, 11^{*}, 12^{*}$, & 20 \\
Tolerance & $13^{*}, 14^{*}, 15^{*}, 16,17,18,19^{*}, 20^{*}$ & \\
Toleransi & & & 16 \\
& $\begin{array}{c}\text { Non- Ethnic Attitude } \\
\text { Tolerance }\end{array}$ & $21,22,23^{*}, 24,25,26,27,28^{*}, 29,30^{*}, 31$, & \\
& & $32,33^{*}, 34^{*}, 35,36^{*}$ & 36 \\
\hline
\end{tabular}


*unfavorable

Table 2. Blue-Print Skala Ciri-ciri Kematangan Beragama

\begin{tabular}{clcc}
\hline \multicolumn{1}{c}{ VARIABEL } & \multicolumn{1}{c}{ ASPEK } & NOMOR ITEM & JUMLAH \\
\hline & $\begin{array}{l}\text { Well-differentiated and self- } \\
\text { critical (berpengetahuan luas } \\
\text { dan bisa mengkritik diri) }\end{array}$ & $37,38,39^{*}, 40,41,42,43$ & 7 \\
& $\begin{array}{l}\text { Motivational Force (menjadikan } \\
\text { agama sebagai kekuatan } \\
\text { motivasi) }\end{array}$ & $44,45,46,47,48,49,50$ & 7 \\
Kematangan Beragama Consistency (moralitas & $51,52,53^{*}, 54,55^{*}$ & 5 \\
Mang konsisten) & $56,57,58,59,60,61,62$ & 7 \\
Komprehensif & $63,64,65,66,67$ & 5 \\
Integral & $68^{*}, 69,70$ & 3 \\
\hline Heuristic & Jumlah & 34 & 34 \\
\hline
\end{tabular}

\section{Hasil dan Pembahasan}

Hasil Uji Validitas Instrumen

Penulis menggunakan analisis factor konfirmatori (confirmatory factor analysis / CFA) untuk menguji valid atau tidaknya item pada instrument penelitian. Pada CFA terdapat beberapa kriteria suatu dinyatakan valid. Dikutip dari Umar (dalam Roebianto, 2010) bahwa kriteria item yang valid pada analisis CFA yaitu:

1. Melihat signikan atau tidaknya koefisien muatan factor pada item. Jika nilai koefisien muatan factor pada item memiliki nilai $\mathrm{t}>1.96$, maka item tersebut signifikan mengukur dimensi/konstruk yang hendak diukur

2. Koefisien muatan factor sesuai dengan favorable/unfavorable item tersebut. Jika item sudah diskoring dengan cara favorable, maka item harus bermuatan positif dan sebaliknya

3. Pada kondisi dimana item terlalu banyak korelasi kesalahan pengukuran, ada baiknya item yang demikian didrop pada saat digunakan untuk kepentingan analisis lebih lanjut. Hal ini disebabkan item yang demikian dikatakan tidak unidimensional.

Berdasarkan hasil analisis CFA dari 35 item variable toleransi beragama diperoleh hasil item yang valid yaitu sebagai berikut:

Tabel 3. Hasil Uji Validitas CFA Toleransi Beragama

\begin{tabular}{cccccc}
\hline Dimensi & No Item & Koefisien & Standar Error & T-Value & Keterangan \\
\hline & 2 & 0.63 & 0.06 & 10.566 & Valid \\
& 3 & 0.61 & 0.08 & 7.515 & Valid \\
& 4 & 0.552 & 0.07 & 7.88 & Valid \\
Ethnic - Attitude & 5 & 0.618 & 0.059 & 10.426 & Valid \\
& 10 & 0.501 & 0.071 & 7.025 & Valid \\
& 11 & 0.46 & 0.082 & 5.625 & Valid \\
& 13 & 0.746 & 0.042 & 17.879 & Valid \\
& 15 & 0.915 & 0.027 & 33.854 & Valid \\
& 16 & 0.851 & 0.034 & 24.949 & Valid \\
& 18 & 0.81 & 0.067 & 12.075 & Valid \\
\hline
\end{tabular}


TAZKIYA (Journal of Psychology), 9(1), 2021

\begin{tabular}{lccccc}
\hline & 20 & 0.625 & 0.047 & 13.163 & Valid \\
& 21 & 0.721 & 0.045 & 15.845 & Valid \\
Non-ethnic & 23 & 0.673 & 0.041 & 16.3 & Valid \\
Attitude & 24 & 0.662 & 0.053 & 12.504 & Valid \\
& 25 & 0.884 & 0.031 & 28.29 & Valid \\
& 26 & 0.38 & 0.068 & 5.627 & Valid \\
& 28 & 0.53 & 0.064 & 8.256 & Valid \\
& 29 & 0.483 & 0.064 & 7.492 & Valid \\
& 31 & 0.719 & 0.043 & 16.719 & Valid \\
\hline
\end{tabular}

Berdasarkan table 6.1 diatas, beberapa item yang dinyatakan tidak valid yaitu item no 1, 6, 7, 8, 9, $12,14,17,19,22,27,30,32,33,34,35$. Item - item yang tidak valid tersebut akan dihapus pada saat menghitung factor skor pada variable toleransi beragama. Kemudian gambar daripada hasil analisis CFA penulis sajikan pada gambar berikut ini

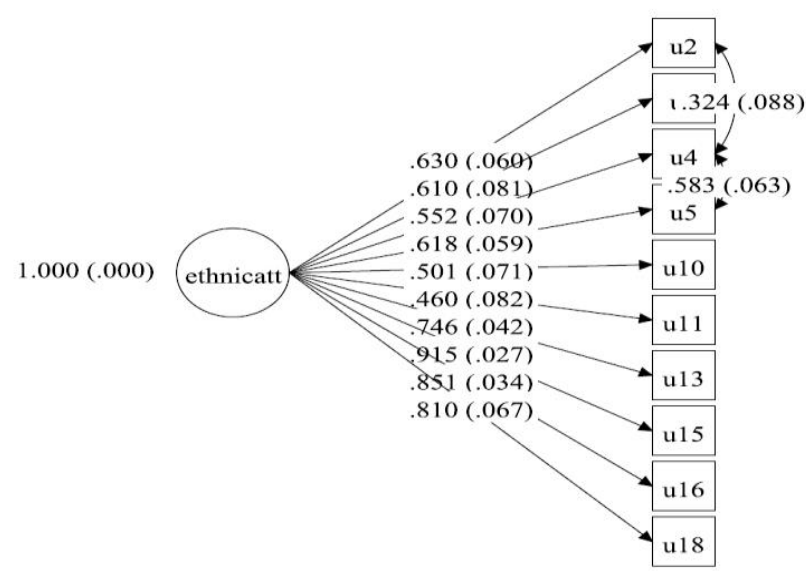

Gambar 1 CFA Ethnic Attitude

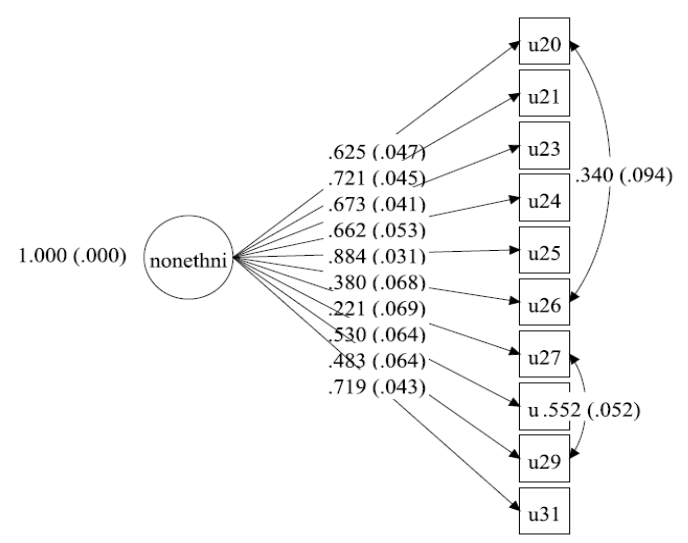

Gambar 2 CFA Non-ethnic Attitude

Pada hasil analisis CFA dari 35 item variable kematangan beragama, item yang dinyatakan valid yaitu item berikut ini:

Tabel 4. Hasil Uji Validitas CFA Kematangan Beragama

\begin{tabular}{lccccc}
\hline \multicolumn{1}{c}{ Dimensi } & No Item & Koefisien & Standar Error & T-Value & Keterangan \\
\hline \multirow{2}{*}{ Well- } & 37 & 0.894 & 0.132 & 6.754 & Valid \\
differentiated \& & 39 & 0.509 & 0.09 & 5.621 & Valid \\
self-critical & 41 & 0.355 & 0.084 & 4.234 & Valid \\
& 42 & 0.44 & 0.091 & 4.847 & Valid \\
\hline Motivational & 43 & 0.833 & 0.027 & 30.72 & Valid \\
force & 44 & 0.844 & 0.025 & 33.379 & Valid
\end{tabular}


TAZKIYA (Journal of Psychology), 9(1), 2021

\begin{tabular}{lccccc} 
& 45 & 0.931 & 0.018 & 52.409 & Valid \\
& 46 & 0.855 & 0.026 & 33.279 & Valid \\
& 47 & 0.762 & 0.038 & 20.209 & Valid \\
Moral & 48 & 0.852 & 0.034 & 25.415 & Valid \\
consistency & 49 & 0.755 & 0.041 & 18.319 & Valid \\
\hline \multirow{4}{*}{ Komprehensif } & 50 & 0.642 & 0.062 & 10.407 & Valid \\
& 51 & 0.965 & 0.07 & 13.813 & Valid \\
& 53 & 0.73 & 0.073 & 10.063 & Valid \\
\hline \multirow{3}{*}{ Integral } & 56 & 0.854 & 0.027 & 31.272 & Valid \\
& 57 & 0.928 & 0.02 & 46.661 & Valid \\
& 58 & 0.959 & 0.032 & 29.832 & Valid \\
& 60 & 0.766 & 0.039 & 19.806 & Valid \\
& 61 & 0.515 & 0.051 & 10.035 & Valid \\
& 62 & 0.75 & 0.039 & 19.419 & Valid \\
\hline & 63 & 0.769 & 0.06 & 12.858 & Valid \\
& 64 & 0.941 & 0.031 & 30.632 & Valid \\
& 65 & 0.927 & 0.045 & 15.804 & Valid \\
& 66 & 0.689 & 0.034 & 27.557 & Valid \\
& 67 & 0.68 & 0.055 & 12.471 & Valid \\
& 68 & 0.728 & 0.04 & 16.913 & Valid \\
& 69 & 0.824 & 0.061 & 11.939 & Valid \\
& 70 & 0.782 & 0.075 & 10.924 & Valid \\
& 69 & 0.064 & 12.262 & Valid \\
\hline
\end{tabular}

Berdasarkan tabel diatas, item yang dinyatakan tidak valid yaitu item 36, 38, 40, 52, 54, dan 55 . Semua item yang tidak valid tersebut tidak akan digunakan dalam menghitung factor skor. Dengan demikian, peneliti akan memiliki dua skor variable yaitu toleransi beragama dan kematangan beragama. Kedua skor tersebut akan digunakan pada saat menghitung tingkat toleransi beragama di kota Tangerang.

\section{Hasil Uji Statistik Deskriptif}

Pada bagian ini penulis akan memaparkan hasil deskriptif dari variable demografi. Adapun variable demografi yang penulis masukkan ke dalam penelitian ini yaitu jenis kelamin, usia, agama dan pendidikan. Sebagai informasi, total partisipan dalam penelitian ini sejumlah $150(\mathrm{n}=150)$ semuanya adalah warga Kota Tangerang. Pengumpulan data tersebut dilakukan secara online sebab penelitian ini dilakukan selama masa Pembatasan Sosial Berskala Besar (PSBB) berlangsung yang diakibatkan oleh pandemic Covid-19.

Hasil daripada analisa deskriptif pada variable demografi tersebut dapat dilihat pada tabel 6.1 berikut ini

Tabel 5. Hasil Deskriptif Variabel Demografi

\begin{tabular}{lccccccc}
\hline & \multicolumn{2}{c}{ JK } & \multicolumn{5}{c}{ Pendidikan } \\
\cline { 2 - 4 } Frekuensi & Pria & Wanita & & SMA & Diploma & Sarjana & Pascasarjana \\
\cline { 2 - 6 } \cline { 5 - 8 } Percentase (\%) & 25 & 115 & & 67 & 11 & 66 & 6 \\
Total Sampel (n) & 23.3 & 76.7 & & 44.7 & 7.3 & 44 & 4 \\
\hline
\end{tabular}

Pada penelitian ini, pria $(\mathrm{n}=35 ; 23.3 \%)$ relative lebih sedikit dibandingkan dengan wanita yang berjumlah 115 atau sekitar $76.7 \%$. Sedangkan berdasarkan demografi pendidikan, tingkat pendidikan Sarjana dan SMA paling banyak diantara partisipan dengan nilai n yaitu 66 (44\%) dan 67 (44.7\%). 
Kemudian diikuti dengan diploma sebesar 11 partisipan $(n=6)$ atau $7.3 \%$ dan terakhir tingkat pendidikan pascasarjana dengan jumlah hanya 6 partisipan $(n=6 ; 4 \%)$.

Kemudian untuk variable usia, penulis menggunakan histogram untuk pemaparannya, sebab variable usia merupakan variable kontinum. Adapun hasilnya dapat dilihat pada figure berikut ini.

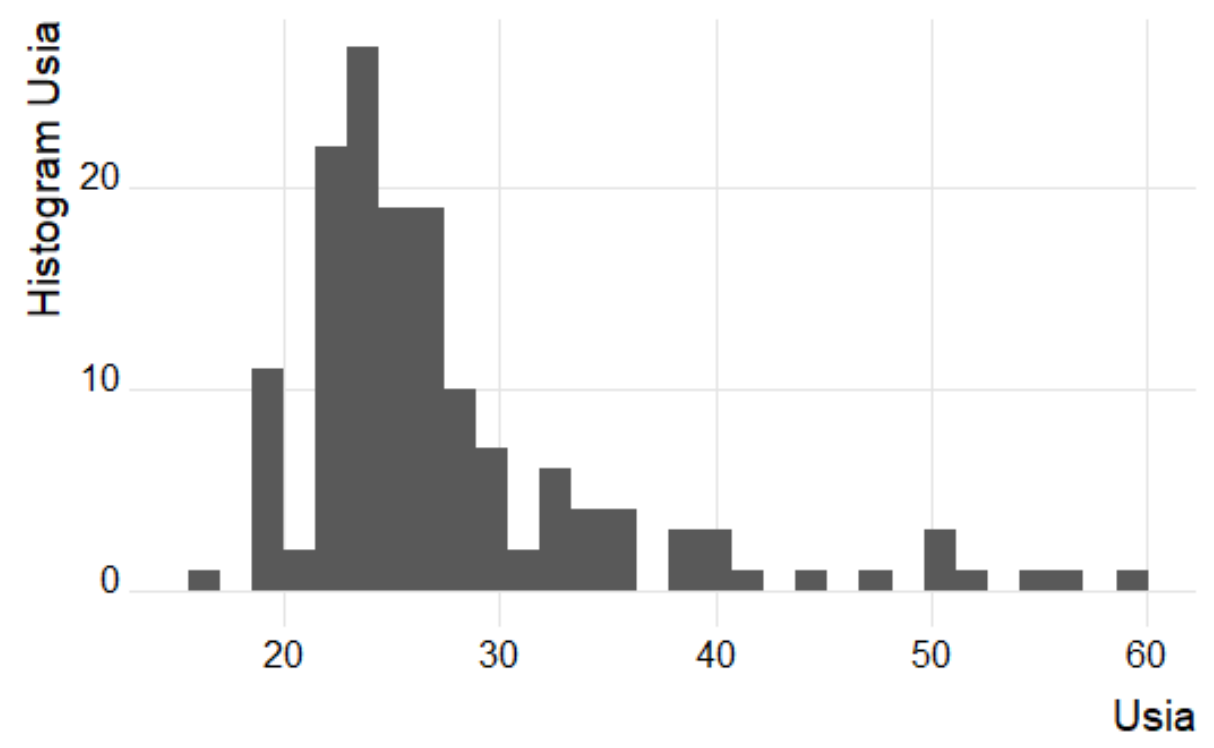

Gambar 3 Histogram Usia Partisipan

Berdasarkan figure diatas terlihat penyebaran usia partisipan cukup menyebar mulai dari usia 17 tahun hingga 60 tahun. Adapun mean dari distribusi usia tersebut yaitu 25.00 sedangkan mediannya yaitu 27.53. Oleh karena itu mayoritas usia partisipan berada di antara rentangan sekitar 20 tahun hingga 40 tahun.

Selanjutnya penulis juga memaparkan distribusi histogram dari variable toleransi beragama dan kematangan beragama. Sebagai informasi, untuk kepentingan kemudahan penggunaan skala pada variable toleransi beragama dan kematangan beragama, maka penulis menggunakan mean skala sebesar $10(\mu=10)$ dan standar deviasi sebesar $1\left(S_{x}=1\right)$. Dengan kata lain, pada kedua variable tersebut, mean dan standar deviasi yang penulis gunakan yaitu 10 dan 1 . Hasil daripada analisa deskriptif kedua variable tersebut yaitu sebagai berikut.

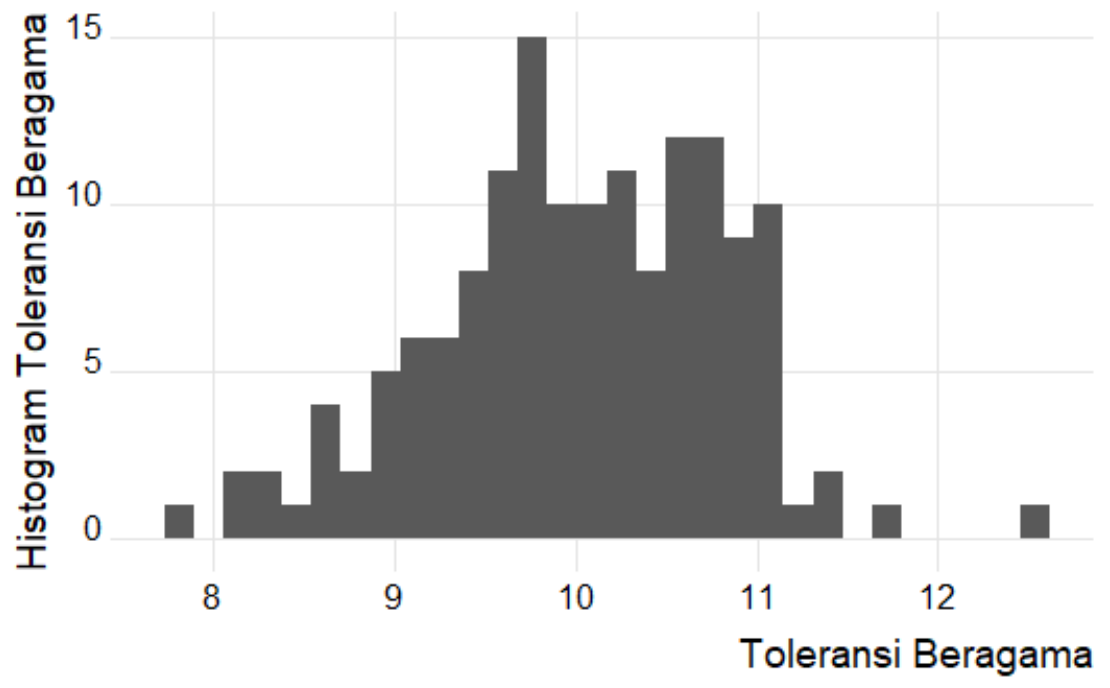

Gambar 4 Histogram Toleransi Beragama 


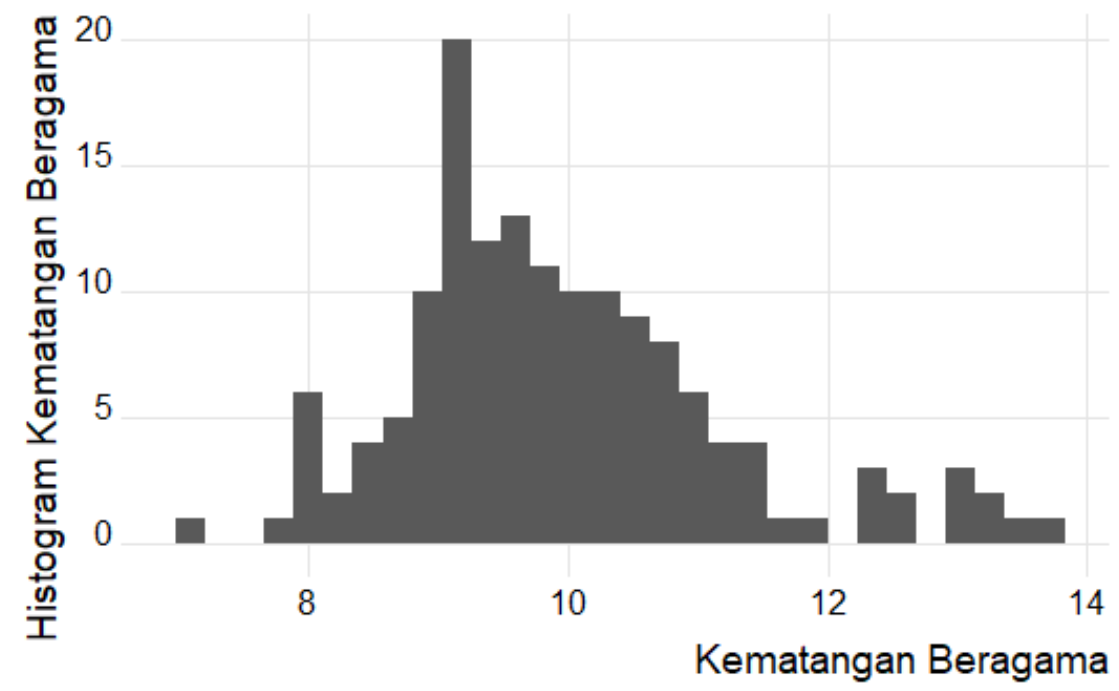

Gambar 5. Histogram Kematangan Beragama

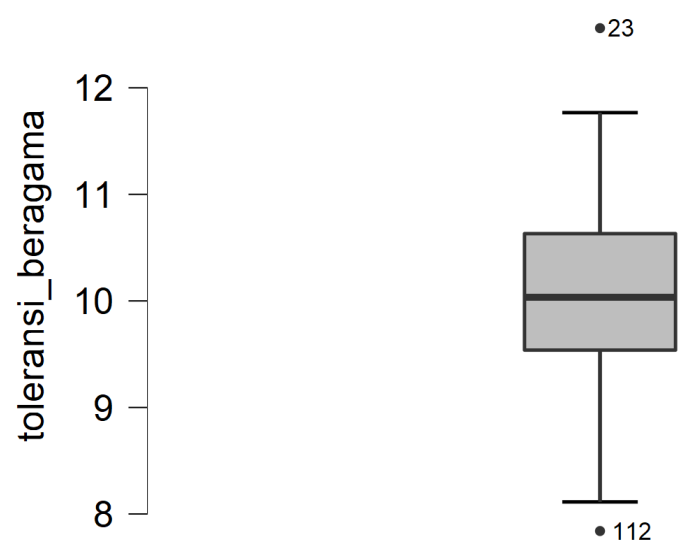

Total

Gambar 6. Boxplot Toleransi Beragama
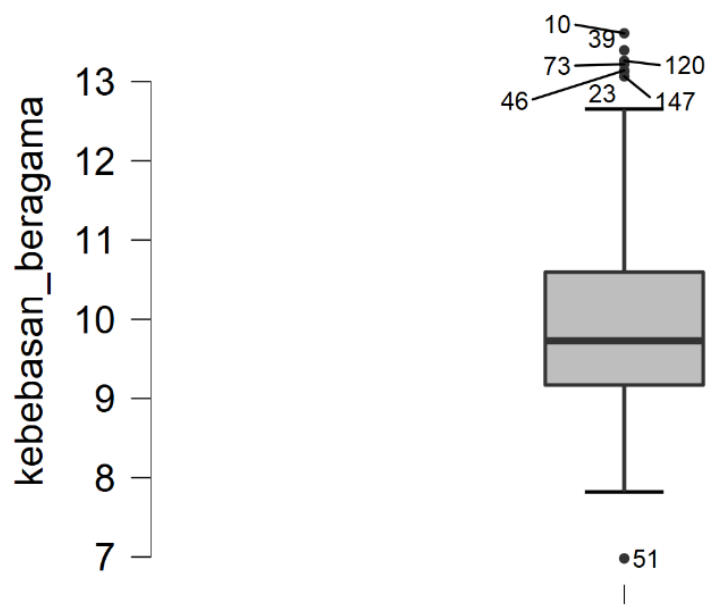

Total

Gambar 7. Boxplot Kebabasan Beragama

Berdasarkan empat figure diatas, terlihat bahwa kedua variable dapat dikatakan berdistribusi normal. Tetapi, pada gambar boxplot terlihat bahwa terdapat beberapa outliers baik pada variable 
toleransi beragama dan kematangan beragama. Pada toleransi beragama, orang yang terlabel sebagai outliers yaitu orang ke-23 dan 112. Sedangkan pada variable kematangan beragama, orang yang dinyatakan sebagai outliers yaitu orang ke-39, 10, 120, 73, 46, 23, 147 dan 51. Peneliti tidak akan menghapus data tersebut, dikarenakan tujuan penelitian ini yaitu melihat bagaimana tingkat toleransi beragama dan kebebasan beragama di Kota Tangerang. Oleh karena itu, pada bagian berikutnya peneliti akan memaparkan hasil kategorisasi skor tinggi, sedang dan rendah pada distribusi toleransi beragama dan kebebasan beragama.

Pada variable toleransi beragama, nilai terendahnya yaitu 7.84, sedangkan nilai tertingginya yaitu 12.56. Sedangkan mean empiric variable toleransi beragama yaitu sebesar 10.03. Kemudian pada variable kematangan beragama, nilai terendahnya yaitu 6.98, sedangkan nilai tertingginya yaitu 13.61. Sedangkan mean empiric variable kematangan beragama yaitu sebesar 9.96.

Kemudian peneliti membuat kategorisasi variable toleransi beragama dan kematangan beragama berdasarkan mean dan standar deviasi hipotetik $\left(\mu=10 ; S_{x}=1\right)$. Adapun hasilnya sebagai berikut:

Tabel 6. Frekuensi Kategorisasi Toleransi Beragama

\begin{tabular}{cccc}
\hline Kategori & Frekuensi & Percent $(\boldsymbol{\%})$ & Kriteria \\
\hline Outlier Bawah & 1 & .67 & $\leq-2 \mathrm{SD}$ \\
Rendah & 16 & 10.67 & $-2 \mathrm{SD}<\mathrm{X} \leq-1 \mathrm{SD}$ \\
Sedang & 119 & 79.33 & $-1 \mathrm{SD}<\mathrm{X} \leq 1 \mathrm{SD}$ \\
Tinggi & 13 & 8.67 & $1 \mathrm{SD}<\mathrm{X} \leq 2 \mathrm{SD}$ \\
Outlier Atas & 1 & .67 & $2 \mathrm{SD}<\mathrm{X}$ \\
Missing & 0 & 0 & - \\
Total & 150 & 100 & - \\
\hline
\end{tabular}

Tabel 7. Frekuensi Kategorisasi Kematangan Beragama

\begin{tabular}{cccc}
\hline Kategori & Frekuensi & Percent $(\boldsymbol{\%})$ & Kriteria \\
\hline Outlier Bawah & 6 & 4 & $\leq-2 \mathrm{SD}$ \\
Rendah & 21 & 14 & $-2 \mathrm{SD}<\mathrm{X} \leq-1 \mathrm{SD}$ \\
Sedang & 100 & 66.67 & $-1 \mathrm{SD}<\mathrm{X} \leq 1 \mathrm{SD}$ \\
Tinggi & 11 & 7.33 & $1 \mathrm{SD}<\mathrm{X} \leq 2 \mathrm{SD}$ \\
Outlier Atas & 12 & 8 & $2 \mathrm{SD}<\mathrm{X}$ \\
Missing & 0 & 0 & - \\
Total & 150 & 100 & - \\
\hline
\end{tabular}

Tabel 9. Statistik Deskriptif

\begin{tabular}{lcc}
\hline & Toleransi Beragama & Kematangan beragama \\
\hline Valid & 150 & 150 \\
Missing & 0 & 0 \\
Mean & 10.022 & 9.953 \\
Std. Deviasi & 0.800 & 1.255 \\
Skewness & -0.185 & 0.825 \\
Std. Error of Skewness & 0.198 & 0.198 \\
Kurtosis & 0.124 & 0.814 \\
Std. Error of Kurtosis & 0.394 & 0.394 \\
Minimum & 7.840 & 6.981 \\
Maksimum & 12.560 & 13.610 \\
\hline
\end{tabular}


Pada tabel 6 \& 7 terlihat bahwa kategorisasi responden umumnya berada pada kategori sedang. Namun demikian, pada tabel 7 terlihat bahwa terdapat sekitar $12 \%$ responden yang masuk ke dalam kategori outlier (jumlah outlier atas dan bawah). Hal ini dapat diartikan ada beberapa partisipan dalam penelitian ini yang memiliki tingkat kematangan beragama yang sangat tinggi ataupun sangat rendah. Kemudian jika dilihat dari hasil deskriptif pada variable tersebut, didapati bahwa kematangan beragama memiliki nilai skewness sebesar .825, yang artinya distribusi kematangan beragama partisipan di Kota Tangerang relative agak di sisi kiri mean. Dengan demikian, distribusi kematangan beragama masyarakat Kota Tangerang memang sedikit agak rendah.

Secara gambaran umum, pada tahapan ini penulis akan memaparkan apakah ada perbedaan toleransi beragama dan kematangan beragama yang dikaitkan dengan variable demografis, seperti jenis kelamin, usia dan pendidikan. Penulis akan melakukan uji beda mean pada tiap variable berdasarkan kelompok - kelompok tersebut.

Perlu diketahui untuk kelompok usia, penulis membagi kelompok usia menjadi tiga kelompok yaitu rentang usia $17-25$ tahun, $26-40$ tahun dan 41 tahun sampai 60 tahun. Pembagian kelompok usia tersebut didasarkan pada teori dari Papalia dkk (2009) yang menyatakan bahwa transisi dari remaja akhir (17 tahun) ke usia 25 tahun disebut sebagai dewasa muda. Rentangan usia 26 hingga 40an awal disebut dewasa madya, sedangkan lebih dari 40 tahun disebut sebagai dewasa akhir. Adapun hasil analisa inferensial dari tiap variable tersebut dapat dilihat pada tabel berikut ini.

Tabel 10. Uji Beda Mean Demografi

\begin{tabular}{|c|c|c|c|c|c|c|c|c|c|}
\hline & \multicolumn{2}{|c|}{$\begin{array}{c}\text { JENIS } \\
\text { KELAMIN }\end{array}$} & \multicolumn{3}{|c|}{ USIA } & \multicolumn{4}{|c|}{ PENDIDIKAN } \\
\hline & Pria & Wanita & $\begin{array}{l}<=25 \\
\text { tahun }\end{array}$ & $\begin{array}{c}26-40 \\
\text { tahun }\end{array}$ & $\begin{array}{l}>=41 \\
\text { tahun }\end{array}$ & SMA & Diploma & Sarjana & $\begin{array}{c}\text { Pasca } \\
\text { Sarjana }\end{array}$ \\
\hline Toleransi & 10.05 & 10.01 & 10.15 & 9.91 & 9.6 & 10.10 & 9.48 & 10.05 & 9.74 \\
\hline Beragama & $(.135)$ & $(.074)$ & $(.092)$ & (.098) & $(.181)$ & $(.097)$ & $(.312)$ & $(.091)$ & $(.258)$ \\
\hline Kematangan & 9.87 & 9.97 & 10.03 & 9.78 & 10.23 & 9.74 & 10.64 & 10.03 & 10.12 \\
\hline Beragama & $(.228)$ & $(.114)$ & $(.147)$ & $(.131)$ & $(.580)$ & $(.140)$ & $(.460)$ & $(.144)$ & $(.927)$ \\
\hline
\end{tabular}

Berdasarkan tabel 10 diatas, penulis mendapati bahwa tidak ada perbedaan mean yang signifikan berdasarkan variable demografi, meskipun secara empiris didapati perbedaan mean antar kelompok.
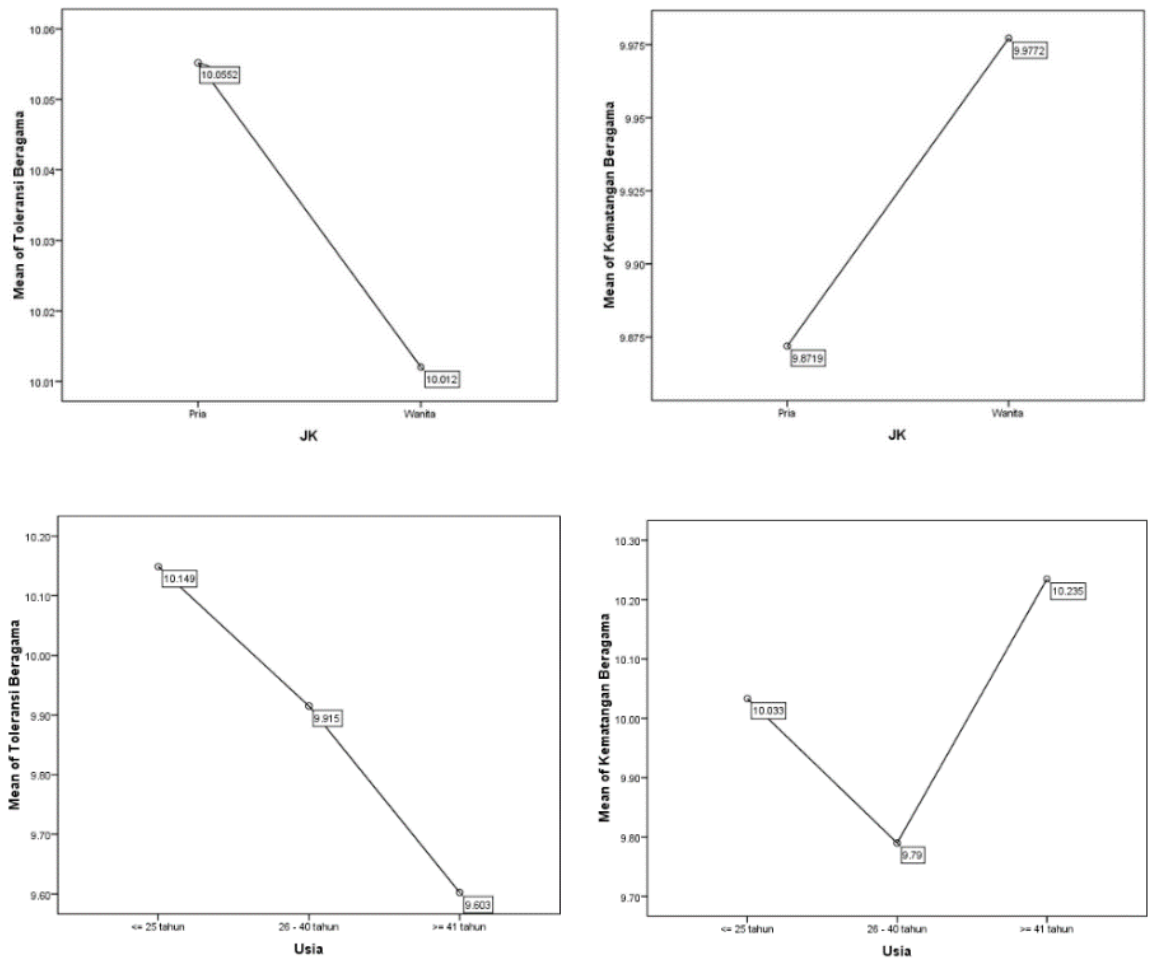

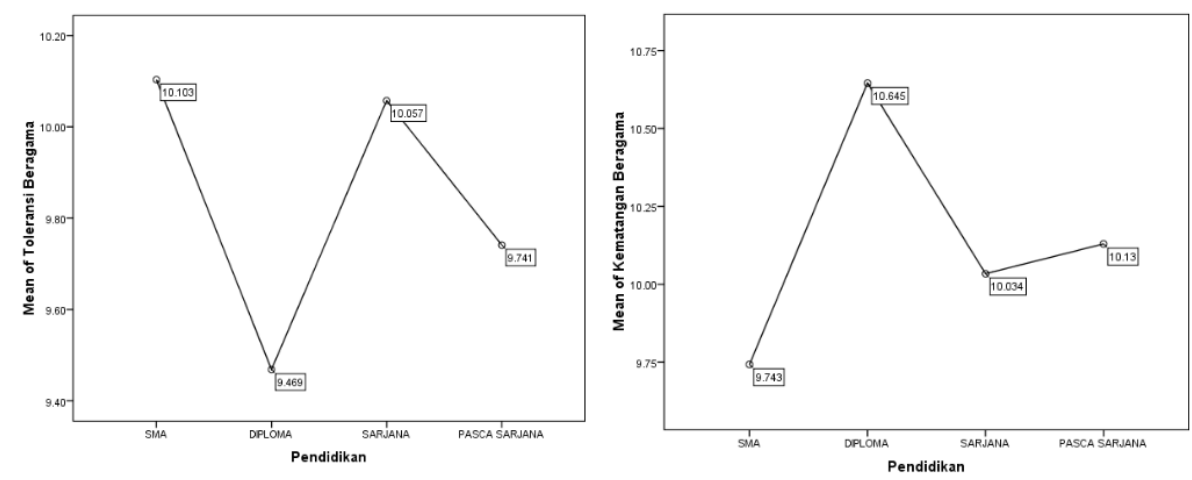

Gambar 7. Hasil Mean Plots berdasarkan Jenis Kelamin, Usia dan Pendidikan

\section{Diskusi}

Berdasarkan hasil pemaparan didapati bahwa distribusi skor toleransi dan kematangan beragama masyarakat kota Tangerang berada pada kategori yang normal atau sedang. Maka dari itu, hasil penelitian ini menunjukkkan bahwa tingkat toleransi dan kematangan beragama di kota Tangerang tergolong normal. Kondisi tersebut berlaku umum tanpa dibedakan berdasarkan jenis kelamin, factor usia dan Pendidikan.

Hasil riset ini sejalan dengan hasil penelitian yang dilakukan oleh Amalia \& Nanuru (2018), dimana mereka mendapati bahwa tingkat toleransi agama di Bali, Papua \& Maluku cenderung tinggi terhadap pemeluk agama lain. Dengan kata lain, meskipun terdapat perbedaan agama namun tidak memengaruhi sikap toleransi antar pemeluk beragama. Kemudian Hermawati \& Paskarina (2016) juga mendapati hasil yang sejalan mengenai toleransi di kota Bandung. Dalam penelitiannya Hermawati \& Paskarina menyimpulkan bahwa kota Bandung memiliki indeks toleransi sebesar 3,82 yaitu tergolong tinggi.

Secara khusus peneliti memang belum mendapati studi yang membahas mengenai toleransi beragama di kota Tangerang. Tetapi dari penelitian lain seperti Alganih (2016), Hafidzi (2019) bahwasannya toleransi di suatu wilayah didasari atas konsep hubungan horizontal yang kuat antar sesama makhluk Tuhan. Lebih jauh lagi, kondisi budaya dan perokonomian ikut menentukan kemungkinan suatu konflik dapat terjadi. Namun demikian, salah satu unsur yang berperan penting adalah tokoh masyarakat atau tokoh agama dalam menyelaraskan kehidupan antar umat beragama di suatu wilayah.

Sebagaimana diketahui bahwa terdapat banyak rumah ibadah di Kota Tangerang, baik itu masjid untuk ummat Islam, gereja untuk umat Kristiani/Nasrani, vihara untuk umat Buddha dan Klenteng untuk ummat Khonghucu. Pada tiap rumah ibadah tersebut memiliki tokoh agama masing-masing, sehingga para tokoh tersebut yang berperan penting dalam menyampaikan pesan toleransi antar ummat beragama. Dapat dikatakan bahwa kota Tangerang adalah kota yang majemuk dari segi agama dan etnisnya. Oleh karenanya pesan-pesan toleransi tersebut menjadi penting untuk kehidupan bermasyarakat di kota Tangerang dan umumnya di Indonesia.

\section{Kesimpulan}

Berdasarkan hasil penelitian diatas, penulis dapat menyimpulkan beberapa point sebagai berikut: Secara umum, hasil gambaran deskriptif pada variable toleransi beragama dan kematangan beragama dinyatakan berdistribusi normal, dimana hampir sekitar minimal $68 \%$ berada pada kategori sedang. Namun demikian, terdapat dua catatan utama pada bagian ini. Pertama, berdasarkan nilai skewness variable kematangan beragama terdistribusi cenderung ke arah kiri atau agak rendah. Kemudian, variable kematangan beragama juga memiliki outlier cases, baik outlier bawah maupun atas. Dengan demikian, tingkat toleransi beragama masyarakat Kota Tangerang dapat dikatakan normal. Tetapi pada variable kematangan beragama, masyarakat Kota Tangerang agak rendah tingkat 
kematangannya dan bahkan ada beberapa yang nilai kematangan beragamanya sangat rendah, tetapi hal ini sifatnya kasuistik (beberapa).

Dari semua variable demografi yaitu jenis kelamin, usia dan pendidikan, tidak ada satupun yang perbedaannya signifikan secara statistik. Maka itu, dapat dikatakan factor demografi pada penelitian ini tidak berpengaruh signifikan dalam memandang toleransi dan kematangan beragama. Jumlah sample yang tidak merata pada masing-masing kategori mempengaruhi kuat hasil penelitian ini. Seperti subyek penelitian didominasi oleh jenis kelamin perempuan. Selain itu pula kategori Pendidikan didominasi pada jenjang SMA sebanyak $44,7 \%$ dan $44 \%$ pada jenjang Pendidikan Sarjana. Pada penelitian sebelumnya dengan jumlah sampel yang seimbang pada jenis kelamin lakilaki dan perempuan sebanyak 250 subyek pada pemuda di Malaysia (Khadijah, 2019) menyebutkan bahwa tidak terdapat perbedaan signifikan toleransi beragama laki-laki dan perempuan. Dari semua variable demografi, hanya kelompok agama yang dinyatakan signifikan perbedaannya dalam hal variable toleransi beragama. Namun demikian, menurut penulis, hal tersebut bisa saja terjadi akibat kelompok partisipan pada tiap agama berbeda terlalu jauh. Sebagai gambaran partisipan yang beragama Islam sebesar 83, sedangkan yang beragama Kristen 59 dan terakhir yang beragama Buddha sebesar 8 partisipan.

Selanjutnya berdasarkan pemaparan hasil dan kesimpulan yang ada, maka penulis dapat memberikan saran sebagai berikut untuk ke depannya, sebaiknya dilakukan replikasi penelitian yang sama tetapi dengan cara pengumpulan data yang secara tatap muka langsung, sehingga selain mengisi kuesioner, dapat dilakukan juga wawancara kepada partisipan. Tentu hal ini dilakukan jika masa pandemic Covid-19 sudah selesai. Penelitian ini dilakukan justru ketika pandemic Covid-19 terjadi, sehingga pengumpulan data yang mulanya akan ada pengisian secara langsung menjadi diganti dengan kuesioner online.

Pada penelitian yang akan datang, sebaiknya dilakukan pendataan terlebih dahulu mengenai sampling frame masyarakat Kota Tangerang. Hal ini diperlukan agar mengetahui siapa saja sasaran sampel penelitian yang terdiri dari berbagai macam agama serta karakteristik demografi. Jika hal ini dapat dilakukan, maka hasil penelitian dapat digeneralisasi secara lebih meyakinkan di tingkat populasi. Selain itu untuk mendapat gambaran yang lebih utuh mengenai toleransi beragama di kota Tangeran, akan lebih baik di penelitian berikutnya dapat mengidentifikasi variable-variabel apa yang mempengaruhi tingkat toleransi di kota Tangerang. Menurut Verkuyten \& Yogeeswara (2017) toleransi dan intoleransi adalah dua konsep psikologis yang berbeda sehingga dapat melibatkan variable-variabel yang berbeda Intoleransi juga dapat dilihat dari berbagai perspektif (a) intoleransi prasangka yang didasarkan pada kekakuan, pikiran tertutup, dan antipati terhadap sekelompok orang; (b) intoleransi intuitif yang melibatkan ketidaksetujuan terhadap keyakinan atau praktik di luar kelompok berdasarkan tanggapan yang tidak reflektif; dan (c) intoleransi yang disengaja, yang melibatkan campur tangan terhadap keyakinan atau praktik tertentu yang dianggap melanggar prinsip dan nilai moral. Ketiga pemahaman ini memiliki implikasi yang berbeda untuk (a) bagaimana menanggapi intoleransi dan (b) bagaimana ketidaksepakatan tentang interpretasi contoh intoleransi dapat menghasilkan perbedaan yang tidak dapat didamaikan antara kelompok budaya, agama, dan ideologis (Verkuyten, Adelman, \& Yogeeswaran, 2020). Hal ini yang akan sangat menarik untuk melihat lebih mendalam bagaimana dinamika toleransi dan intoleransi di masyarakat Kota Tangerang.

\section{Daftar Pustaka}

Alganih, I. (2016). Konflik Poso: Kajian Historis tahun 1998 - 2001. Jurnal CRIKSETRA, (5), 10, $166-174$.

Amalia, A., \& Nanuru, R.F. (2018). Toleransi Beragama Masyarakat Bali, Papua \& Maluku. Jurnal Darussalam: Jurnal Pendidikan, Komunikasi dan Pemikiran Hukum Islam, (10), 1, 150 - 161.

Allport, W. (1954). The Nature of Prejudice. Cambridge MA: Addison-Wesley. 
Badan Pusat Statistik. (2018). Jumlah Penduduk Menurut Kecamatan dan Jenis Kelamin di Kota Tangerang tahun 2018. Diambil pada tanggal 27 Maret 2020 dari https://tangerangkota.bps.go.id/dynamictable/2018/11/21/97/jumlah-penduduk-menurutkecamatan-dan-jenis-kelamin-di-kota-tangerang-2018.html

Cinu, S. (2017). Agama, Militerisasi dan Konflik: Kasus Poso, Sulawesi Tengah. Jurnal Ilmiah Keislaman, (15), 1, $1-49$.

Clark, W.H. (1968). The Psychology of Religion: An Introduction to Religious Experience and Behavior. New York: The MacMillan Company.

Departemen Agama Republik Indonesia. (2002). Al Qur'an dan Terjemahnya. Semarang: Karya Toha Putra.

Dister, N.S. (1988). Psikologi Agama. Yogyakarta: Kanisius.

Fritzsche, Sylke (2006) 'Multikulturelle Schülerschaft und Fremdenfeindlichkeit', in Werner Helsper, Heinz-Hermann Krüger, Sylke Fritzche, Sabine Sandring, Christine Wiezorek, Oliver Böhm-Kasper and Nicolle Pfaff (eds) Unpolitische Jugend? Eine Studie zum Verhältnis von Schule, Anerkennung und Politik, pp. 75-96. Wiesbaden: Verlag für Sozialwissenschaften.

Golebiowska, E. A. (1999). Gender gap in political tolerance. Political Behavior, 21(1), 43-66.

Gunawan, H, (2002). Toleransi Beragama Menurut Pandangan Hamka dan Nurcholos Majid. Skripsi: Universitas Muhammadiyah Surakarta.

Hafidzi, A. (2019). Konsep Toleransi dan Kematangan Agama dalam Konflik Beragama di Masyarakat Indonesia. Potret Pemikiran, (23), 2, 51 - 61.

Hermawati, R., \& Paskarina, C. (2016). Toleransi Antar Umat Beragama di Kota Bandung. UMBARA: Indonesia Journal of Anthropology, 1, 105 - 115.

Jalaludin, (2001). Psikologi Agama. Jakarta: Raja Grafindo Persada.

Juwita, W, Salim, A, Winarno, W. (2018). Students' Tolerance Behavior in Religious-Based Primary School: Gender Perspective. International Journal of Educational Research Review, 3 (3), 5158. DOI: $10.24331 /$ ijere.426255

Khadijah, M., Mastor, K.A., Fazilah, I., \& Tohar S.A. (2019). Faktor Demografi dalam Toleransi Beragama dalam kalangan Belia di Malaysia. Sains Insani, (4), 2, 76 - 81.

Kristensen, K. B., Pedersen, D. M., \& Williams, R. N. (2001). Profiling religious maturity: The relationship of religious attitude components to religious orientations. Journal for the Scientific Study of Religion, 40(1), 75-86.

Mangunwijaya, Y. B. (1986). Menumbuhkan Sikap Religiusitas Anak. Jakarta: Gramedia.

Papalia, D.E., Olds, S.W., \& Feldman, R.D. (2009). Human Development. 11th Ed. New York: McGraw-Hill Companies, Inc.

Roebianto, A. (2010). Beberapa faktor psikologis yang mempengaruhi prestasi belajar mahasiswa di bidang statistika $1 \& 2$. Skripsi: UIN Syarif Hidayatullah Jakarta: Fakultas Psikologi.

Sabiq, A.F. (2020). Analisis Kematangan Beragama dan Kepribadian serta Korelasi dan Kontribusinya terhadap Sikap Toleransi. Indonesian Journal of Islamic Psychology, (2), 1, 23 $-49$.

Setara Institute. (2018). Press Release Indeks Kota Toleran Tahun 2018. Diambil pada 23 Maret 2020 dari https://setara-institute.org/indeks-kota-toleran-ikt-tahun-2018/

Umar, M. (2015). Konflik Tolikara-Papua, Mengungkap Motif dan Solusinya. Diambil pada 25 Maret 2020 dari https://www.kompasiana.com/musniumar/55b8299f92fdfd2c048b4567/konfliktolikarapapua-mengungkap-motif-dan-solusinya?page=all) 
Verkuyten, M., Adelman, L., \& Yogeeswaran, K. (2020). The Psychology of intolerance: Unpacking diverse understandings of intolerance. Current Directions in Psychological Science, 29(5), 467472.

Verkuyten, M., \& Yogeeswaran, K. (2017). The social psychology of intergroup toleration: A roadmap for theory and research. Personality and Social Psychology Review, 21(1), 72-96.

Wagner, Ulrich and Andreas Zick (1995) 'The Relation of Formal Education to Ethnic Prejudice: Its Reliability, Validity and Explanation', European Journal of Social Psychology, 25: 41-56

Weldon, Steven A. (2006) 'The Institutional Context of Tolerance for Ethnic Minorities: A Comparative, Multilevel Analysis of Western Europe', American Journal of Political Science, 50(2): 331-49

Wikipedia. (2020). Diambil dari lama Wikipedia pada 21 Maret 2020 dari https://id.wikipedia.org/wiki/Kerusuhan_Poso 